\title{
Islamic values contained in university students' quatrains in the whatsapp group
}

\author{
Dewi Warna* \\ Program Studi Pendidikan Bahasa Inggris, Fakultas Ilmu Tarbiyah dan Keguruan Universitas Islam Negeri Raden Fatah, \\ Palembang, Indonesia \\ dewiwarna_uin@radenfatah.ac.id \\ ${ }^{*}$ Corresponding author: dewiwarna_uin@radenfatah.ac.id
}

\begin{tabular}{|c|c|c|}
\hline Article History & Received: March 26, 2020 & Available Online: April I5, 2020 \\
\hline \multicolumn{3}{|c|}{ ABSTRACT } \\
\hline \multicolumn{3}{|c|}{$\begin{array}{l}\text { Quatrains used to live among Malays in Indonesia, especially in South Sumatera. But now, not many people in South Sumatera } \\
\text { use quatrains in daily life interactions among people in society. It makes quatrains almost extinct. Fortunately, a group in } \\
\text { whatsapp namely "Grup Pantun Mahasiswa" tries to remain using quatrains in communicating among the group members. } \\
\text { The objective of this research is to find out the Islamic values contained in the quatrains made by the students of Faculty of } \\
\text { Tarbiyah and Teaching Sciences, Indonesia, in the whatsapp group. The method of this research was descriptive qualitative. } \\
\text { In collecting the research data, the researcher collected the quatrains in the whatsapp group since January 2I, } 2019 \text { to July } \\
\text { 2I, 20I9. These quatrains were made by 32I students of Faculty of Tarbiyah and Teaching Sciences as the members of the } \\
\text { whatsapp group. The group's name is "Grup Pantun Mahasiswa". The number of the quatrains was } 649 \text { quatrains. Next, in } \\
\text { analyzing the research data, first of all, the researcher read and presented the quatrains in the whatsapp group. Then she } \\
\text { classified them into topic categories: Islamic and non-Islamic topic categories. The Islamic topic categorized quatrains were } \\
\text { subcategorized into its Islamic values. The Islamic values were then described one by one. The result of the analysis showed } \\
\text { that out of } 649 \text { quatrains Islamic values contained in the quatrains made by the whatsapp group members are the followings: } \\
\text { (I) worshipping God (praying, fasting, and giving alms); (2) the sunnah of marriage; (3) respecting parents; (4) appreciating } \\
\text { elders; (5) diligence in working \& fulfilling invitations; (6) supporting one another in achieving goals; (7) comforting the } \\
\text { sad; (8) asking for forgiveness and forgiving one another; (9) the importance of silaturrahim; (I0) suggestions of doing good } \\
\text { deeds; (II) competing in doing good deeds; (I2) forbidding doing the harms; (I3) helping one another; (I4) praying for } \\
\text { one another's success; (I5) unity among Muslims; and (I6) praising God's creatures. In conclusion, out of 649 quatrains as } \\
\text { the research data, } 5 \text { I quartains contained Islamic values. While, other } 598 \text { quatrains did not contain any Islamic values. }\end{array}$} \\
\hline \multicolumn{3}{|c|}{ Keywords $\quad$ Whatsapp group, Islamic values, Quatrains } \\
\hline \multicolumn{3}{|c|}{ ABSTRAK } \\
\hline \multicolumn{3}{|c|}{$\begin{array}{l}\text { Pantun dulu hidup di antara masyarakat Melayu di Indonesia, terutama di Sumatera Selatan. Tapi sekarang, tidak banyak } \\
\text { orang di Sumatera Selatan menggunakan pantun dalam interaksi kehidupan sehari-hari, kondisi tersebut membuat pantun } \\
\text { hampir punah. Penelitian ini bertujuan untuk mengetahui nilai-nilai Islami yang terkandung dalam pantun karya mahasiswa } \\
\text { Fakultas Ilmu Tarbiyah dan Keguruan, Universitas Islam Negeri Raden Fatah Palembang dalam grup whatsapp. Metode } \\
\text { penelitian yang digunakan dalam penelitian ini adalah deskriptif kualitatif. Data dalam penelitian ini berupa } 649 \text { buah pantun } \\
\text { yang dibuat oleh mahasiswa mahasiswa Fakultas Ilmu Tarbiyah dan Keguruan Universitas Islam Negeri Raden Fatah } \\
\text { Palembang. Sumber data dalam penelitian in berupa grup whatsappyang diberi nama "Grup Pantun Mahasiswa". Selanjutnya, } \\
\text { dalam menganalisis data penelitian, peneliti membaca dan mempresentasikan pantun di grup whatsapp tersebut, kemudian } \\
\text { mengklasifikasikannya ke dalam kategori topik konten Islami dan non-Islami. Pantun-pantun bertopik Islami selanjutnya } \\
\text { disubkategorikan ke dalam nilai-nilai Islami yang terkandung di dalamnya. Nilai-nilai Islami dalam pantun-pantun tersebut } \\
\text { kemudian dideskripsikan satu per satu. Hasil analisis menunjukkan bahwa dari 649 buah pantun, nilai-nilai Islami yang } \\
\text { terkandung dalam pantun-pantun yang dibuat oleh anggota grup whatsapp tersebut adalah sebagai berikut: (I) beribadah } \\
\text { kepada Tuhan (berdoa, berpuasa, dan memberi sedekah); (2) sunnah pernikahan; (3) menghormati orang tua; (4) menghargai } \\
\text { orang-orang yang lebih tua; (5) ketekunan dalam bekerja; memenuhi undangan; (6) saling mendukung dalam mencapai tujuan; } \\
\text { (7) menghibur yang sedang bersedih; (8) meminta maaf dan saling memaafkan; (9) pentingnya bersilaturrahim; (I0) saran } \\
\text { untuk melakukan perbuatan baik; (II) bersaing dalam melakukan perbuatan baik; (I2) melarang melakukan keburukan; (I3) } \\
\text { saling membantu; (I4) saling mendoakan kesuksesan satu sama lain; (I5) persatuan di antara umat Islam; dan (I6) memuji } \\
\text { makhluk ciptaan Tuhan. Sebagai kesimpulan, dari } 649 \text { buah pantun di grup whatsapp yang dianalisis sebagai data penelitian, } \\
\text { 5I buah pantun mengandung nilai-nilai Islami. Sementara, } 598 \text { buah pantun lainnya tidak mengandung nilai-nilai Islami. }\end{array}$} \\
\hline & & $\begin{array}{l}\text { Copyright@2020, Dewi Warna } \\
\text { ticle under the CC-BY-3.0 license }\end{array}$ \\
\hline & & \\
\hline
\end{tabular}




\section{INTRODUCTION}

In everyday life, people in society usually deal with literature whether they realize it or not. The literature can be in the form of written literature or in the form of oral literature which is called folklore. Literature itself is defined by Klarer (2013) as works written in the artistic or aesthetic language. So, he differentiates between literary works and non literary ones based on the language the works contain or written in. In Latin, literature is called "literatura" which can be concluded as coherent texts which are formed from words and sentences becoming one unity. However, according to him, these definitions cannot help us categorize texts into literary works or non-literary ones. He suggests us investigate the condition of the production and reception of the texts.

While folklore is understood as the artworks produced by people from lower social strata, regardless of its developmental phases. Thus, folklore is a class phenomenon. Compared to literature, which is also a class phenomenon, folklore is different. Under a socialist society which does not know upper and lower strata, folklore loses its specific features. People no longer recognize that folklore is produced by people from lower strata. It has been national property. Since not many people use it and produce it, it changes significantly qualitative and comes closer to literature (Propp, I984). This thing might happen because folklore, compared to literature, is transmitted orally and not well documented. Inevitably, over time, folklore might be extinct.

Propp's statement might be true for other kinds of folklore like folktales that folklore is a product of lower strata. However, quatrains are the products of the majority of Indonesian Malays, from lower strata to upper strata. It is proved that quatrains are used by a group of people consisting of educated people, in this case university students, to communicate and express their ideas in their daily interactions in the whatsapp group.

Some efforts are done by people to preserve folklore. One example was conducted by (Eb, Ouhalla, \& Owens, 20I). They investigated the collection of oral traditions (folklore) in Saudi Arabia which is called mukhadram. They documented the folklore in written forms.

Another effort for preserving folklore done by some people by documenting folklore into films. They put the goals of documentary and ethnodocumentary films into one film called folklore films. Thus, this film has two goals namely to publish unrecorded events and to give cultural information to spectators. This kind of film visualizes traditional aspects starting from folk, rituals, religious procedures, cultural components like quatrains, dances, songs and so on. People who watch this kind of film are united by the cultural contents of this film no matter their backgrounds are Zhang (2015) as cited in Sherman and Koven (2007). Zhang defines filmic folklore as imaginary folklore that appears only in films, and is created in the fiction genre. Taken out of the original contexts as its history, geography, culture, and social background. It also functions to publish unrecorded events and to give cultural information to spectators just like the functions of folklore films. The folklore in filmic folklore may be in the forms of verbal or non-verbal (2005) as cited in Sherman and Koven (2007).

As one kind of folklore, quatrains need to be preserved just like other kinds of folklore which are preserved in the form of films and written documents. One effort which has been done is by using quatrain in communication. In this case, a group in whatsapp namely "Grup Pantun Mahasiswa" tries to remain using quatrains in communicating among the group members.

Why do quatrains need to be preserved? It is because quatrains are one kind of folklore which become people's tradition in Indonesia, they have been alive for years among Indonesian people and are used in the interaction among them in daily life interaction and communication. But nowadays, quatrains in Indonesia are almost extinct. Not many people, especially the young generation for example university students, remain using quatrains in communication among them. 
In addition, quatrains are products of literature which are very well known in vernaculars all over Indonesia. Generally, quatrains consist of four lines with an introduction in the first two lines and content in the second two lines. The introduction are is usually related to nature (featuring the culture of the users' society) and often it is not related to the content which is the goal of the quatrain (Agni, 2009) as cited in (Iswary \& Hasanuddin, 2010). In this case, quatrains are a medium of expressing people's minds, emotions, opinions and disagreement in an indirect and fun way.

Quatrains function as the caretaker of language and as a medium of sharpening minds in order to be more creative. Besides, to use quatrains, people tend to spontaneously think associatively because quatrains are word plays and message transmitters (Iswary \& Hasanuddin, 20I0).

This is in line with Propp's statement (1997) that actually as a kind of folklore, quatrains are useful in socializing moral values, especially Islamic values indirectly. Folklore becomes more and more important right now since all aspects of our life cannot be separated from folklore. We have become more aware that to transmit the messages of moral values and spiritual culture, we can use folklore.

As it is done to folklore in general which is preserved in the form of folklore film, quatrains are also being preserved by the students of Faculty of Tarbiyah and Teaching Sciences in their daily interaction in the whatsapp group. The whatsapp group members realize that if quatrains have no medium for preservation, quatrains will be extinct someday. This means we cannot inherit this kind of folklore to the young generation. Thus, the researcher got interested to find out the hidden spiritual culture in quatrains. In this case, the hidden spiritual culture in the quatrains is Islamic values.

The problem of this research is formulated in the following question: "What are the Islamic values contained in the quatrains made by the students of the Faculty of Tarbiyah and Teaching Sciences, Indonesia, in the whatsapp group?"

The objective of this research is to find out the Islamic values contained in the quatrains made by the students of Faculty of Tarbiyah and Teaching Sciences, Indonesia, in the whatsapp group.

Some research on folklore have been conducted. The first one was conducted by (Fitriyah, 2016). She investigated folklore which is delivered through a radio in Jakarta. The folklore is reflection. She focused on its vocabulary and figurative expressions. The finding of the research showed that some specific Javanese vocabulary were used in the reflections she investigated. The specific Javanese vocabulary was boyong, ruwatan, katimbang, simbah, mondok, keseleo, merubung, pamrih-pamruh, and sulut. Figurative expressions she found in the reflections were climax, hipalase, oximoron, metaphor, personification, and allusion. The similarity between the research and the researcher's research lies on the folklore. The difference is that the former investigated reflections, but the latter investigated quatrains. Besides, the reflections in the former were transmitted through radio, but the quatrains in the latter were transmitted through social media (whatsapp Application).

The second study Windiatmoko, (2017) used a descriptive qualitative research design. It aimed at finding out grammatical and lexical textual aspects, contextual aspects and intertextual aspects. It also aimed at the character education in the couplets XII written by Raja Ali Haji. Couplets are two lines of verse, usually metered and joined by rhyme, that form a unit. The specific result of the values of character education found in this study covered honesty, reading fondness, and social care (Windiatmoko, 2017). The similarity between Windiatmoko's research and the researcher's lies on the aim of finding out character education (Islamic values). Both research also used the same research design, namely a descriptive qualitative research design. While the difference lies on the data investigated. Windiatmoko investigated couplets, but the researcher investigated quatrains.

Another study on quatrain aimed at describing the learning of quatrain writing in terms of the teaching and learning plan, the teaching activities, and the learning assessment done by the teacher. This is qualitative descriptive research. The results show that all elements investigated were in accordance with the assessment indicators (Tampubolon, 2017).

The next research also investigated quatrains, in this case, the skill of writing quatrains. This research aims at describing the ability to write rhymes with the quantum learning model of teaching to Junior High School students. The method used in this research is descriptive qualitative. The results of 
this research showed that the systematic aspects of writing, use of language, and clarity of the contents, obtained an average value of 84 . It means that students' skill in writing quatrains is very good (Gafar, 20I4).

Those three research investigated quatrain writing skills. the subjects are non-university students. Meanwhile, the research conducted by the researcher focused on the Islamic values of quatrains made by university students.

Another study on quatrain ascertains the perspective of Malay quatrain in media technology. The subjects were given a website which consists of Malay quatrain activities. The results of the study revealed that the subjects would prefer (Normaliza, Sujud, Affendi, \& Roslan, 2012).

Usually, studies on quatrains are closely related to divinity values or local wisdom as the ones done by (Arditiya, 2017) and (Nugroho, Lazuardi, \& Murti, 2019). Arditiya's study aimed at describing the process of internalizing the divinity values in the novel entitled Orang-Orang Proyek which was written by Ahmad Tohari, and the latter study focused on local wisdom the researchers wanted the students to have through the materials of quatrains.

Some studies on the use of whatsapp application have been also conducted. They will be discussed at glance here just to give a short description on the popularity of whatsapp application among users all over the world, especially in Indonesia. Some studies on the use of whatsapp application were conducted by some researchers in the domains of Islamic teachings and education. Among others are the ones done by (Elianur, 2017; Harahap, 2018; Jumiatmoko, 2016; Sahidillah \& Miftahurrisqi, 2019; Widhiyasari, Umami, \& Suja, 2019).

In general, a study on the usage of whatsapp application focusing on gender differences was conducted by Rungta in Mumbai, India. This study showed that gender influenced the usage of whatsapp in the area of usage of emoticons, being members of groups, the active time during the day, changing profile pictures and status, sharing emotional outbursts, and sending pictures of their shopping (Rungta, 2015).

The similarity between Rungta's research and this research lies on the use of the whatsapp application. The difference is that Rungta investigated the whatsapp usage in general, but this research investigated quatrains made by students transmitted in the whatsapp group, especially the Islamic values the quatrains contained.

While the use of whatsapp application for the purpose of preaching is a form of a shift of a preaching tradition among Islamic Religion Education teachers and preachers. Preaching activities used to be done face to face among the preachers and the audience. They used to be often done at mosques or large fields with a preaching duration of two-five hours. Only two-way interactions took place, interactions from the preachers to the audience or from the audience to the preachers. The topics which could be discussed in one preaching session were limited to amount number (five to ten topics).

What about nowadays? Preaching activities are not only done face to face among the preachers and the audience, but also from social media, especially via whatsapp application. They cannot only be done at mosques or large fields with preaching duration of two-five hours, but via whatsapp application, preaching activities can be done for unlimited time with three-way interactions, interactions from the preachers to the audience or from the audience to the preachers, and interactions among the audience. The topics discussed in one preaching session are unlimited. In brief, preaching activities via whatsapp application have more strengths compared to the conventional preaching activities.

A study done by Harahap (2018) proved that the preacher could interact closely with a lot of audience $(\mathrm{IOO}+)$ in one group called "Belajar Islam Seru" with unlimited topics, especially problems of daily lives analyzed from Islamic law. Three-way interactions happened, interactions from the preacher to the audiences, from the audience to the preachers, and interactions among the audience. However, in longer periods, group members who joined in the interaction in the group became less and less. One reason which might cause that thing is that the materials (in this case the Islamic values or law) were 
transmitted rather seriously, through ordinary lectures or common notes. Thus, the activities became monotonous and made the members of the group got bored.

The novelty of this research lies in the fun preaching activities compared to the one described before. The preaching activities were not monotonous and boring. Automatically, the group members felt enthusiastic to join the interaction by reading and making quatrains. They also commented on the Islamic values the quatrains contained actively and highlight. They also did one of the efforts of preserving quatrains which used to live in Malay society in South Sumatera so that they will not be extinct. The transmission of preservation is through a medium which is frequently used by the young people, whatsapp application. Whatsapp has been a trending medium for communication among all generations, not only young generation, for its simplicity and its efficient safe internet quota when being used. Besides, the most important issue this research carries is "character education.' Specifically, this moral education is inserted subconsciously in the messages the quatrains contain. This automatically leads to repair the students' moral degradation. The quatrains in the whatsapp group subconsciously become an effective medium of "preaching."

\section{METHOD}

The method of this research was descriptive qualitative. According to Sandelowski in (Lambert \& Lambert, 20I2), descriptive qualitative studies should be treated as categorical or non-categorical investigation. They are least interpreted by the researchers rather than interpretative descriptive studies because in descriptive qualitative studies, it is not obligatory for the researchers to move far from or in the research data. Not like phenomenology, grounded theory or ethnography which are also included in the qualitative research designs, the researchers must not render very conceptual or abstract data in descriptive qualitative studies. Besides, descriptive qualitative studies are least burdened by existing theoretical or philosophical commitments. They tend to be in natural investigations, to dig up research data in a possible natural setting of research contexts.

Qualitative research is defined as interpretive research. This research lies in an investigation that relies heavily on observers defining and redefining the meanings of what they see and hear (Stake, 2010).

Lune and Berg (2016) states qualitative research refers to meanings, concepts, definitions, characteristics, metaphors, symbols and descriptions of things.

The nature of outputs of qualitative research according to Snape and Spencer (2003) is the followings:

a. Producing detailed descriptions;

b. Mapping meanings, processes and contexts;

c. Describing the whole things including the mechanisms and the reasons of things happen;

d. Considering that researchers' perspectives might affect the results of their research;

e. Small purposive sampling;

f. Data are collected by involving direct interaction between the researcher and the research participants and allow further exploration;

g. Providing extensive and detailed data;

h. An analysis which leads the production of detailed description and classification, identify patterns of association, or develop typologies and explanations;

i. Producing interpretative outputs through mapping and representing the social world of research participants.

In this case, this research describes Islamic values contained in the quatrains made by the students of the Faculty of Tarbiyah and Teaching Sciences in the whatsapp group. The members of this whatsapp group come from different cultural background since they come from different regencies in South Sumatera (not only from Palembang) like from Muara Enim, Lahat, Musi Rawas, Muratara, Musi Banyuasin, Banyuasin, Lubuk Linggau, PALI, Ogan Komering Ulu, Ogan Ilir, and Ogan Komering Ilir.

In collecting the research data, the researcher collected the quatrains in the whatsapp group from January 2I, 2019 to July 2I, 20I9. These quatrains were made by 32I students of the Faculty of Tarbiyah 
and Teaching Sciences as the members of the whatsapp group. The group's name is "Grup Pantun Mahasiswa”. The number of quatrains was 649 quatrains.

Next, in analyzing the research data, first of all, the researcher read and presented the quatrains in the whatsapp group. Then she classified them into topic categories: Islamic and non-Islamic topic categories. The Islamic topic categorized quatrains were subcategorized into its Islamic values. The Islamic values were then described one by one.

\section{FINDING AND DISCUSSION}

In this part, the writer will present the results of this research and its analysis. From 469 quatrains investigated, only 5I quatrains which had Islamic topics. While the rest had non-Islamic topics that they could not be investigated further. Most of these quatrains were written in Indonesian and only a few of them were written in vernaculars (Palembangnese and Muara Enimnese) and in English.

One example of a quatrain written in Indonesian is the following:

Duduk merenung di bangku taman,

tidak terasa sudah sepekan.

Kasih orang tua sepanjang zaman,

Karena itu, janganlah dilupakan.

One example of a quatrain written in Palembangnese is the following:

Anak mudo harus kreatif.

Harus jugo sopan dan santun.

Betjiwo mudo untuk hal-hal positif.

Misalnyo ngasah hobi bepantun.

One example of a quatrain written in Muara Enimnese is the following:

Lemak benau tahuk sawi.

Tahuk sawi diputiw dari ume.

Payu kite same begawi.

Mangke pacak jadi jeme.

One example of a quatrain written in English is the following:

Ten thousand ways of having a relationship.

Living is knowing how to love each other.

One key for growing a nice friendship.

Giving and taking makes us caring for one another.

Completely, Islamic Values in the Quatrains made by students of the Faculty of Tarbiyah and Teaching Sciences in the whatsapp group are the following.

I. Worship to God (praying, fasting, and giving alms)

(a) Kado besar dihias pita.

Diberikan kepada siswa.

Semoga amal ibadah kita, membuat kita lebih bertaqwa.

(b) Dari Tanjung Baru ke Tanjung Karang.

Tunai bayarkan cangkul dan kail.

Kami baru bangun lagi sekarang.

Usai tunaikan Qiyamul lail.

(c) Jika salah tolong diingatkan,

agar Allah selalu berkenan.

Sholat malam ditunaikan,

Untuk meningkatkan keimanan. 
(d) Sibuk sang tukang mengukir meja.

Meja terbuat dari pohon kelapa.

Walaupun kita sibuk bekerja,

sholat 5 waktu jangan sampai alpa.

(e) Tubuh pak tani berlumur tanah,

karena membajak tanah sampai rata.

Puasa Senin Kamis puasa sunnah,

untuk menambah pahala kita.

(f) Belajar ngaji dengan Ustad Amin.

Mengkaji Alqui'an tak kenal lelah.

Amiiin ya robbal A'lamiiin.

Ya Allah, mohon kabulkanlah.

(g) Jadi orang jangan serakah,

kalau serakah bisa gelap mata.

Sungguhlah amal sedekah,

berfungsi mensucikan harta.

The quatrains (a), (b), (c), (d), (e), (f) and (g) in (I) contain Islamic values, namely worship to God (praying, fasting, and giving alms). In (a), the indicators of the Islamic values are the words 'ibadal' and 'taqwa'; in (b), the words 'qiyamul lail; in (c), the words 'Allah', 'sholat malam' and 'keimanan'; in (d), the word 'sholat'; in (e), the words 'puasa sunnah' and 'pahala'; in (f), the words 'Amiiin ya robbal A'lamiiin' and 'Allah'; and in (g), the words 'sedekah' and 'mensucikan harta.'

2. The Sunnah of Matriage

(a) Air Musi mengalir deras.

Mengalimna dari hulu ke kampung pak Sakir.

Milih bini jangan gino bepikir keras.

Yang penting seiman, baik budi dan baik pikit.

(b) Jika ada ide, boleh mengusul.

Usul itu dapat kita diskusikan.

Menikah adalah sunnah rasul.

Jadi baiknya disegerakan.

(c) Duduk sarapan di meja makan.

Makannya susu dengan sereal.

Aaamiiin, semoga didapatkan.

Sosok istri setia yang ideal.

The quatrains (a), (b), and (c) in (2) contain Islamic values, namely the sunnah of marriage. In (a), the indicators of the Islamic values are the words 'seiman', 'baik bud' and 'baik pikit'; in (b), the words 'sunnah rasul and 'disegerakan'; and in (c) the words 'aaamiiin' and 'istri setia.'

\section{Respecting Parents}

(a) Duduk merenung di bangku taman,

tidak terasa sudah sepekan.

Kasih orang tua sepanjang zaman,

Karena itu, janganlah dilupakan.

(b) Air mengalit di daun keladi.

Daunnya licin tak terkoyakkan.

Marilah kita membalas budi.

Seperti yang telah mereka lakukan. 
The quatrains (a) and (b) in (3) contain Islamic values, namely respecting parents. In (a), the indicators of the Islamic values are the words 'kasih orang tua' and 'janganlah dilupakan'; and in (b), the words 'membalas budi.'

4. Appreciating Elders

(a) Peras kelapa mengambil pati. Kelapa dipanjat oleh junior. marilah kita saling menghormati dan menghargai para senior.

(b) Takkan lari rusa dikejar, karena larinya seputar taman. Marilah kita terus belajar. Kepada yang berpengalaman.

The quatrains (a) and (b) in (4) contain Islamic values, namely appreciating elders. In (a), the indicators of the Islamic values are the words 'menghormati and 'menghargai para senior'; and in (b), the words 'belajar' and 'berpengalaman.'

\section{Diligence in Working}

(a) Kodok melompat di tepi kali, langsung ditangkap oleh si Minin. Besok harus bekerja kembali. Mari semangat menjelang Senin.

(b) Alangkah masam si buah pelam. Pohon pelamnya tumbuh di halaman. Dalam kesibukan kita tenggelam, laptop dan berkas menjadi teman.

(c) Ada untung ada rugi. Kita pasrahkan saja. Teman-teman, selamat pagi. Selamat semangat bekerja.

(d) Semua orang tidaklah sama. Masing-masing memiliki daya. Hari Senin hari pertama. Selamat bekerja dan berkarya.

The quatrains (a), (b), (c), and (d) in (5) contain Islamic values, namely diligence in working. In (a), the indicators of the Islamic values are the words 'bekerja kembali and 'semangat'; in (b), the words 'kesibukan' and 'laptop dan berkas'; in (c), the words 'semangat bekerja'; and in (d), the words 'bekerja dan berkarya.'

\section{Fulfilling Invitations}

(a) Sungguh indah dipandang mata, tumbuh subur si pohon rotan. Wajib hukumnya bagi kita, memenuhi undangan hajatan.

(b) Mari kita hindari peperangan, agar hidup kita menjadi tenang. Ayo rame-rame kita kondangan, agar yang punya hajat merasa senang. 
The quatrains (a) and (b) in (6) contain Islamic values, namely fulfilling invitations. In (a), the indicators of the Islamic values are the words 'wajib hukumnya' and 'memenuhi undangan'; and in (b), the words 'rame-rame kondangan' and 'yang punya hajat senang'

7. Supporting One Another in Achieving Goals

(a) Barang bermerk harganya mahal.

Di tokonya tanya sama penjaga.

Ibu memang pintar dalam segala hal,

dan suatu saat jadi Doktor juga.

(b) Kondangan makan nasi samin.

Harumnya tercium burung bulbul.

Amiiin ya robbal a'lamiiin.

Semoga doa Ibu terkabul.

(c) Lemak benau tahuk sawi.

Tahuk sawi diputiw dari ume.

Payu kite same begawi.

Mangke pacak jadi jeme.

The quatrains (a), (b), and (c) in (7) contain Islamic values, namely supporting one another in achieving goals. In (a), the indicators of the Islamic values are the words 'pintar' and 'jadi Doktor'; in (b), the words 'Amiiin ya robbal a'lamiiin' and 'doa terkabul'; and in (c), the words 'begawi and 'jadi jeme.'

\section{Comforting the Sad}

(a) Mata merah terasa pedih, tidak sengaja terkena lada. Jangan dikau merasa sedih. Kegagalan sukses yang tertunda.

(b) Pamrih itu berharap pujian, bagai si padi berharap beras. Kegagalanku adalah ujian, agar berusaha lebih keras.

The quatrains (a) and (b) in (8) contain Islamic values, namely comforting the sad. In (a), the indicators of the Islamic values are the words 'jangan sedil' and 'kegagalan sukses yang tertunda'; and in (b), the words 'kegagalan adalah ujian' and 'berusaha lebih keras.'

\section{Asking for Forgiveness and Forgiving One Another}

(a) Harum semerbak daun pandan.

Dibuat stikaya untuk dimakan.

Sebelum tiba puasa ramadan, Segala salahku mohon dimaafkan.

(b) Padat rumah di perkotaan.

Berbaris di kiri juga di kanan.

Mohon dimaafkan perkataan,

Maupun perbuatan yang tak berkenan.

(c) Terbang tinggi burung pelikan.

Jauhnya sampai di ujung mata.

Akupun telah memaafkan.

Semua khilaf tanpa diminta.

The quatrains (a), (b), and (c) in (9) contain Islamic values, namely asking for forgiveness and forgiving one another. In (a), the indicators of the Islamic values are the words 'puasa ramadhan' and 
'salah mohon dimaafkan'; in (b), the words 'mohon dimaafkan' and 'perbuatan yang tak berkenan'; and in (c), the words 'memaafkan' and 'semua khilaf.

10. The Importance of Silaturrahim

(a) Banyak berteman banyak rahmat. Mari bersama kita mendekat. Banyak sahabat banyak kerabat. Ramaikan dunia indahkan akhirat.

(b) Akrabi keluarga dan kerabat. Baru bisa dikatakan berbudi luhur. Selamat siang, para sahabat. Met makan dan sholat dzuhur.

(c) Simpan jerami di dalam peti. Peti disimpan tidaklah lama. Memang kunci persahabatan sejati, adalah saling memberi dan menerima.

(d) Ten thousand ways of having a relationship. Living is knowing how to love each other. One key for growing a nice friendship. Giving and taking makes us caring for one another.

The quatrains (a), (b), (c), and (d) in (IO) contain Islamic values, namely the importance of silaturrahim. In (a), the indicators of the Islamic values are the words 'banyak kerabat' and 'dunia akhirat'; in (b), the words 'berbudi luhur' and 'sholat dzuhur'; in (c), the words 'persahabatan sejati' and 'memberi dan menerima'; and in (d), the words 'nice friendship' and 'caring one another.'

II. Suggestions of Doing Good Deeds

(a) Anak mudo harus kreatif.

Harus jugo sopan dan santun.

Berjiwo mudo untuk hal-hal positif.

Misalnyo ngasah hobi bepantun.

(b) Sarapan pagi makan ketan.

Sarapannyo di cafetaria.

Kalu kito jago kesehatan,

Insya Allah selalu sehat dan ceria.

(c) Ujan-ujan lemak nggoreng bakwan.

Bakwan dimakan jangan dibiarkan.

Selamat sholat Dhuhur dan makan.

Selamat istirahat siang, kawan-kawan.

(d) Nyabut ubi tak kenal lelah.

Ubi dicabut tinggal serumpun.

Mari kita baca bismillah.

Setiap mengerjakan apapun.

The quatrains (a), (b), (c), and (d) in (II) contain Islamic values, namely suggestions of doing good deeds. In (a), the indicators of the Islamic values are the words 'sopan santun' and 'hal-hal positif; in (b), the words 'jago kesehatan' and 'selalu sehat dan ceria'; in (c), the words 'sholat zhuhur' and 'selamat istirahat'; and in (d), the words 'baca bismillah' and 'setiap mengerjakan apapun.' 
I2. Competing in Doing Good Deeds

(a) Sungguh indah bunga sepatu. Bunga mekar sepanjang waktu. Aduhai memang harus begitu. Cinta sejati tak lekang oleh waktu.

(b) Wanginya bunga mawar dan bunga melati. Bunga kenangapun semerbak juga. Itu namonyo istri sholehah dan baik hati. Suaminyo jugo setia dan siaga untuk keluarga.

(c) Melakukan riset sepanjang waktu, dilakukan dengan metode ilmiah. Alhamdulillah kalu cak itu.

Ubi kayu penyembuh alamiah.

The quatrains (a), (b), and (c) in (I2) contain Islamic values, namely competing in doing good deeds. In (a), the indicators of the Islamic values are the words 'cinta sejati' and 'tak lekang oleh waktu'; in (b), the words 'istri sholehah' and 'suami setia dan siaga'; and in (c), the words 'melakukan riset' and 'penyembuh alamiah'

\section{Forbidding Doing the Harms}

Emas berlian bertahtakan. warna emas terus bertahan.

Janganlah engkau membuat kerusakan.

Jagalah bumi sesuai perintah Tuhan.

The quatrain in (I3) contain Islamic values, namely forbidding doing the harms. The indicators of the Islamic values are the words 'janganlah membuat kerusakan', 'jagalah bumi and 'sesuai perintah Tuhan.'

14. Helping One Another

(a) Berenang-renang ikan betutu, dengan riangnya mencari makan. Jika ada yang dapat dibantu, janganlah sungkan untuk dikatakan.

(b) Yang terhormat nyonya dan tuan, pidato ini mari dengarkan. Terima kasih atas tawaran bantuan. Mohon maaf karena merepotkan.

(c) Sungguh harum bau masakan. Memasak bukanlah suatu beban. Janganlah dikau merasa sungkan. Saling tolong adalah kewajiban.

The quatrains (a), (b), and (c) in (I4) contain Islamic values, namely helping one another. In (a), the indicators of the Islamic values are the words 'dapat dibantu' and 'janganlah sungkan'; in (b), the words 'terima kasih tawaran bantuan' and 'mohon maaf merepotkan'; and in (c), the words 'janganlah sungkan' and 'saling tolong kewajiban.'

\section{I5. Praying for One Another's Success}

(a) Jika lapar, segera makan. Makannya nasi berlauk ikan. Semoga dapat terkabulkan, apa yang dicita-citakan. 
(b) The gangs are in agreement.

That horse rises the bill.

Thanks for the encouragement.

Of course, I will.

The quatrains (a) and (b) in (I5) contain Islamic values, namely praying for one another's success. In (a), the indicators of the Islamic values are the words 'semoga terkabulkan' and 'yang dicita-citakan'; and in (b), the words 'encouragement' and 'I will.'

I6. Unity among Moslems

(a) Terkena panas emas tak lekang. Malah bersinar tak terkalahkan. Anggota grup ini berbeda latar belakang. Hanya pantun yang mempersatukan.

(b) Mentari bersinar panas bedengkang. Bahaso jawo tujuh adalah pitu Biar kito berbeda latar belakang, Dengan pantun kito pacak bersatu.

(c) Bertandang ke rumah pak Alim, ditemani oleh Rukayah. Mari kita sesama muslim, Pererat ukhuwah Islamiyah.

The quatrains (a), (b), and (c) in (I6) contain Islamic values, namely unity among moslems. In (a), the indicators of the Islamic values are the words 'berbeda latar belakang' and 'mempersatukan'; in (b), the words 'berbeda latar belakang' and 'bersatu'; and in (c), the words 'sesama muslim' and 'ukhuwah Islamiyah.'

\section{Praising God's Creatures}

(a) Kerja keras bersimbah peluh, agar keluarga bisa makan. Berayun di air terjun Curup Buluh, pemandangannya cantik menakjubkan.

(b) Menggiring bebek pulang ke kandang.

Biar mudah gunakan satang.

Seluas mata daku memandang, Ada sawah indah terbentang.

(c) Hati-hati dalam meniti. Konsentrasikan pikiran dan mata. Indahnya alam adalah bukti, dari kekuasaan Sang Pencipta.

The quatrains (a), (b), and (c) in (I7) contain Islamic values, namely praising God's creatures. In (a), the indicators of the Islamic values are the words 'air terjun' and 'cantik menakjubkan'; in (b), the words 'seluas mata memandang' and 'indah terbentang'; and in (c), the words 'indahnya alam bukti' and 'kekuasaan Sang Pencipta.'

The findings above are in line with the research finding by (Qarizada \& Sharma, 2017). She investigated a specific kind of quatrain in Afghanistan, namely Rubai. The finding showed that the key features of Rubai are to be eloquent, spontaneous and ingenious. In a Rubai, there are two parts. The first part is the introduction which is the first three lines that is the sublime for the fourth line of the poem. It represents the idea if sublet, pithy and clever (Qarizada \& Sharma, 2017). In the quatrains made in the whatsapp group also applied introduction for the first and the second line (what is called sampiran), and the third 
and the fourth lines state the content or the advice of the whole quatrains the person would like to express (what is called isi).

The quatrains which contained Islamic values were written in bahasa Indonesia, in vernaculars and in English. In English, quatrains are also known. According to (Baldick, I996), a quatrain is a verse of four lines, rhymed is the most commonly used stanza in English and most modern European languages. From those Islamic values, no values were expressed in specific and complicated ways. All were expressed in simple ways because it was difficult to give advice through quatrains because the whatsapp group members needed to consider the first two lines (sampiran or introduction) and the second two lines (contents) in order to have good rhymes (a-b-a-b).

From 649 quatrains investigated in this research, 5 I quatrains contained Islamic values or we can say "religiosity". It is in line with the finding of a study conducted by (Sari, Gusnetti, \& Syofiani, 2013). Their research investigated Minangkabau quatrains in a book entitled I000 Petatah-Petitih, MamangBidal, Pantun-Gurindam" compiled by Idrus Judge of Dt. Rajo Panghulu amounting which consisted of 6I quatrains. According to their finding, religiosity as the most frequent character values contained in $6 \mathrm{I}$ quatrains investigated.

According to the theory of quatrain Hayes and MacEachern (1998) a quatrain is not just a sequence of four lines; it is a pair of pairs, with the following structure:

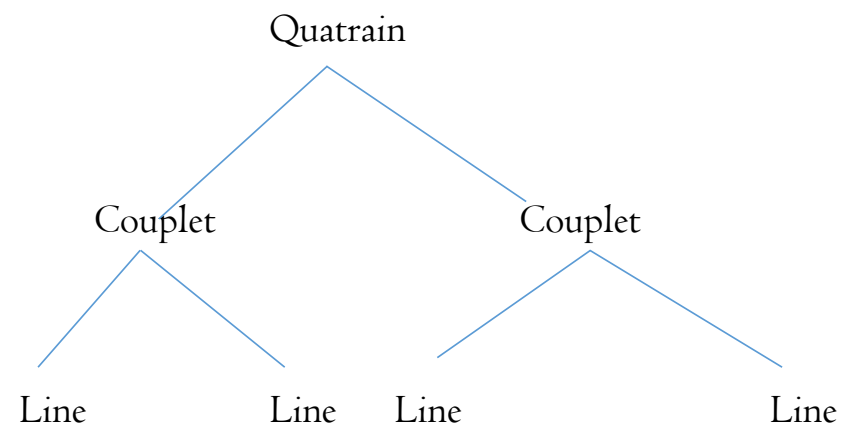

The pair-of-pairs structure is also reinforced by rhyme, through identical couplet-endings $(\mathrm{ABCB})$, couplet-internal parallelism (AABB) and couplet-external parallelism (ABAB).

Compared to the theory above, the findings of this research are in line with the theory of quatrain structure. All quatrains which contained Islamic values were formed by two couplets or four lines. The rhyme adopted couplet-external parallelism (ABAB). This is reflected as in the following quatrain example:

\section{Nyabut ubi tak kenal lelah.(A) \\ Ubi dicabut tinggal serumpun.(B) \\ Mari kita baca bismillah.(A) \\ Setiap mengerjakan apapun.(B)}

The first line and the second line are included in the first couplet and the third line and the fourth line are included in the second couplet.

The researcher analysis applied Birch's theory stating that analysis of the text is therefore carried out as if texts exist in, for, and by themselves, not as part of larger discursive formations (Birch, 2005). Thus, the analysis done towards the research data is treated amply

Thus, the findings of this study supports the following theories:

I. Creativity is recognized to be something common as well as special, ordinary as well as extraordinary, collaborative as well as an individual. It refers to the fact that in practice, creation always involves making something new out of something old and something else out of what already is Pope as cited in (Hall, 2005). 
2. The verse could be used to educate the reader and encourage her to improve morally, collecting Ideas from various Quarters, unite them together and is the principal means by which we make intellectual and moral Improvements (Faubert, 2015). Moral or values according Wicaksono in (Nugroho \& Suseno, 2019), are good in leterary work, covering positive things useful for human' lives and they deserve to have the values.

\section{CONCLUSION}

In conclusion, out of 649 quatrains as the research data, 5 I quatrains contained Islamic values. Meanwhile, other 598 quatrains did not contain any Islamic values. All quatrains which contained Islamic values were formed by two couplets or four lines. The rhyme adopted couplet-external parallelism ( $\mathrm{ABAB})$.

Based on the previous analysis, the Islamic values contained in the quatrains made by the students of Faculty of Tarbiyah and Teaching Sciences in the whatsapp group are the followings: worship to God (praying, fasting, and giving alms); the sunnah of marriage; respecting parents; appreciating elders; diligence in working; fulfilling invitations; supporting one another in achieving goals; comforting the sad; asking for forgiveness and forgiving one another; the importance of silaturrahim; suggestions of doing good deeds; competing in doing good deeds; forbidding doing the harms; helping one another; praying for one another's success; unity among moslems; and praising God's creatures.

In order to preserve quatrains in the world of Indonesian Malays, it is recommended that students intensively make quatrains and use them frequently in every day lives not only through thewhatsapp group. The best topics for their quatrains are the topics of Islamic values. Besides preserving the culture of quatrain usage, they are expected to be more pious moslems because they learn Islamic values in fun ways. Because of the fun transmitting of the Islamic values, they would like to apply the Islamic values consistently in their daily lives as rahmatan lil a'lamiinn.

\section{ACKNOWLEDGMENTS}

Above all, I thank Allah SWT for everything that I can finish this research. I say my gratitude to Dean of Faculty of Tarbiyah and Teaching Sciences, Universitas Islam Negeri Raden Fatah Palembang, for his support and motivation in order that I can finish this research. I am also grateful to the Head of English Education Study Program for her support in administrative matters. To students of English Education Study Program, Faculty of Tarbiyah and Teaching Sciences, Universitas Islam Negeri Raden Fatah Palembang, I owe you one for your cooperation in providing data needed for this research.

\section{REFERENCES}

Arditiya, A. (2017). Internalisasi nilai ketuhanan pada novel Orang-orang Proyek karya Ahmad Tohari. KEMBARA: Jurnal Keilmuan Bahasa, Sastra, dan Pengajarannya, 2(2), II4-I25. doi: https://doi.org/10.22219/kembara.v2i2.3996

Baldick, C. (1996). The concise Oxford dictionary of literary terms. Oxford Oxford University Press.

Birch, D. (2005). Language, literature and critical practice Language, Literature and Critical Practice, 4(2), I-IO. doi: https:// doi.org/I0.4324/9780203976845

Eb, E., Ouhalla, J., \& Owens, J. (20I). Oral poetry and narratives from Central Arabia. In P. M. Kurpershoek (Ed.). Oxford: Brill Academic Publishers.

Elianur, C. (2017). Pemanfaatan aplikasi whatsapp sebagai sarana diskusi antara pengawas dan guru pendidikan agama Islam. Jurnal As-Salam, I(2), I-I4. Retrieved from http://www.jurnalassalam.org/index.php/JAS/article/view/80

Faubert, M. (2015). Rhyming reason: The poetry of romantic-era psychologists. Pickering \& Chatto: Routledge.

Fitriyah, N. (20I6). The use of advertisement to improve student's vocabulary (an experimental study) at the eleventh grade of MA Irtiqaiyah Banjarmasin academic year 2015/20I6. (Thesis), 
Universitas Islam Negeri Antasari Banjarmasin, Banjarmasin Retrieved from http://idr.uinantasari.ac.id/3676/9/lampiran.pdf

Gafar, A. (20I4). Kemampuan menulis pantun dengan model pembelajaran quantum teaching pada siswa kelas VII C SMP Negeri I6 Kota Jambi tahun ajaran 20I4/2015. Pena: Jurnal Pendidikan Bahasa dan Sastra, 4(I), I5-32. doi: https:// online-journal.unja.ac.id/pena/article/view/2332

Hall, G. (2005). Literature in language education. Research and practice in applied linguistics. Oxford: Palgrave Macmillan.

Harahap, H. S. (2018). Whatsapp sebagai media strategi komunikasi ustadzah dalam menyampaikan dakwah (studi deskriptif kualitatif komunitas "belajar Islam seru"). Paper presented at the DiMCC Conference Proceeding, Bekasi.

Hayes, B. P., \& MacEachern, M. (1998). Quatrain form in English folk verse. Language, 74(3), 473507. doi: https:// doi.org/I0.1353/lan.1998.0152

Iswary, E., \& Hasanuddin, F. (2010). Analisis semiotik kultural pantun bahasa Indonesia-Makassar: Dari bilingualisme ke multikulturalisme. Malang. Retrieved from http://sastra.um.ac.id/wpcontent/uploads/2010/0I/055-Ery-Iswary-UnHas-Analisis-Semiotik-Kultural-...-..pdf.

Jumiatmoko, M. (2016). Whatsapp messenger dalam tinjauan manfaat dan adab. Wahana Akademika: Jurnal Studi Islam dan Sosial, 3(I), 5I-66. doi: http:/ / dx.doi.org/I0.2I580/wa.v3iI.872

Klarer, M. (2013). An introduction to literary studies. London: Routledge.

Lambert, V. A., \& Lambert, C. E. (20I2). Qualitative descriptive research: An acceptable design. Pacific Rim International Journal of Nursing Research, I6(4), 255-256.

Lune, H., \& Berg, B. L. (2016). Qualitative research methods for the social sciences. Needham Height, MA: Allyn \& Bacon.

Normaliza, A. R., Sujud, A., Affendi, N. R. N., \& Roslan, S. N. A. (2012). A Perspective of Malay Quatrain in media technology. Revista de Administratie Publica si Politici Sociale, I(8), 40-49. Retrieved from http://revad.uvvg.ro/files/nr8/4.\%20Abd\%20Rahim.pdf

Nugroho, Lazuardi, D. R., \& Murti, S. (2019). Pengembangan bahan ajar LKS menulis pantun berbasis kearifan lokal siswa kelas VII SMP Xaverius Tugumulyo. KEMBARA: Jurnal Keilmuan Bahasa, Sastra, dan Pengajarannya, 5(I), I-I2. doi: https://doi.org/I0.22219/kembara.v5iI.8352

Nugroho, \& Suseno, S. (2019). Analisis nilai moral pada cerpen surat kabar suara merdeka edisi bulan Oktober sampai Desember 2017 sebagai alternatif bahan ajar SMA kelas XI. Jurnal Pendidikan Bahasa dan Sastra Indonesia, 8(2), I I 5-I 19. doi: https:/ / doi.org/I0.I5294/jpbsi.v8i2.28542

Propp, V. I. A. k. (1984). Theory and history of folklore. Minnesota: Manchester University Press.

Qarizada, M., \& Sharma, S. K. (2017). Poetry in translation: A comparative analysis of selected works of Rabia Balkhi and Nadia Anjuman. (Thesis), Lovely Professional University, India. Retrieved from

http:// dspace.lpu.in:8080/jspui/bitstream/I23456789/2387/I / I I6I3704_I I_27_2017 \%204_48_04\%20PM_fileI.pdf

Rungta, S. (2015). Whatsapp usage differences amongst genders: An exploratory study. Indian Journal of Marketing, 45(5), 27-37. doi: https://doi.org/I0.17010/ijom/2015/v45/i5/79938

Sahidillah, M. W., \& Miftahurrisqi, P. (2019). Whatsapp sebagai media literasi digital siswa. Jurnal VARIDIKA, I(I), 52-57. doi: https://doi.org/I0.239I7/varidika.vIiI.8904

Sari, M., Gusnetti, \& Syofiani. (2013). Nilai-nilai pendidikan karakter dalam pantun Minangkabau. Abstract of Undergraduate, Faculty of Education, Bung Hatta University, I(6), I-I2. Retrieved from

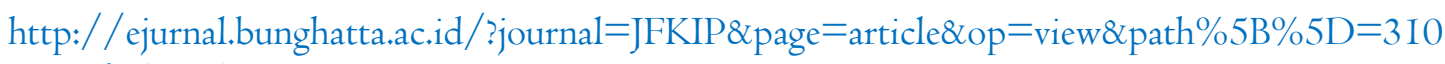
48path\%5B $\% 5 \mathrm{D}=2685$

Sherman, S. R., \& Koven, M. J. (2007). Folklore/cinema: popular film as vernacular culture. Logan, Utah: Utah State University Press.

Snape, D., \& Spencer, L. (2003). Qualitative research practice: A guide for social science students and researchers. London: Sage Publications. 
Stake, R. E. (2010). Qualitative research: Studying how things work. New York: The Guiford Press.

Tampubolon, E. P. (2017). Pembelajaran menulis pantun di kelas XI SMA Negeri I Metro tahun pelajaran 20I6/20I7. (Skripsi), Universitas Lampung Retrieved from http://digilib.unila.ac.id/id/eprint/26I5I

Widhiyasari, M., Umami, N., \& Suja, I. S. (2019). Pengaruh penggunaan media sosial whatsapp terhadap keaktifan siswa pada mata pelajaran ekonomi bisnis kelas X SMK Negeri 2 Boyolangu tahun ajaran 2018/2019. Jurnal Pendidikan Ekonomi, I2(2), 94-98. Retrieved from http://journal2.um.ac.id/index.php/jpe/article/view/8983/4536

Windiatmoko, D. U. (2017). Analisis wacana dalam gurindam XII dan nilai pendidikan karakter serta implikasinya sebagai materi ajar sastra. KEMBARA: Jurnal Keilmuan Bahasa, Sastra, dan Pengajarannya, 2(I), I2-22. doi: https://doi.org/I0.22219/kembara.v2i1.4016

Zhang, J. (2015). Chinese American culture in the making: Perspectives and reflections on diasporic folklore and identity. The Journal of American Folklore, I28(5I0), 449-475. Retrieved from https://muse.jhu.edu/article/59843I 